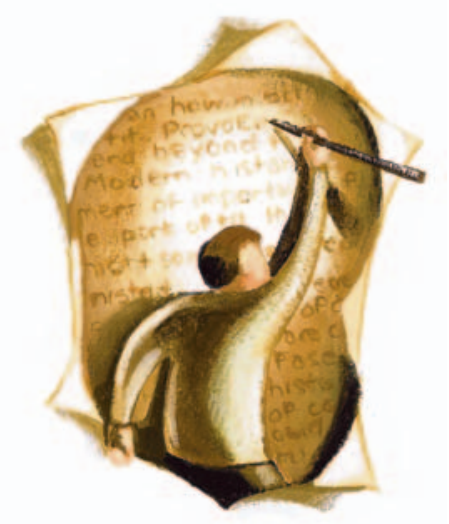

\section{Reflections on the birth of}

\section{conjoined twins}

How refreshing it was to read Ken Walker's article. ${ }^{1} \mathrm{He}$ has the courage to speak out on a subject from which most of us shy away. The major concern of physicians since the time of Hippocrates has been to help prevent pain and suffering; the concept of saving lives at all costs is a modern aberration. In the time of Hippocrates, deformed or malformed babies were put out on the hillside to perish. Of course such a practice would be abhorrent today, but one has to reflect on the enormous cost to our current system of performing heroic procedures on patients whose viability is doubtful.

\section{Glanville Davies BSc MB BCh Surrey, BC}

Competing interests: None declared.

\section{REFERENCE}

I. Walker K. The tragedy that should never have happened. $C M A J$ 2007;177:312.

DOI:I0.I503/cmaj.I070I24

Doctors have one duty to fulfill above all others: the alleviation of suffering. Implicit in this duty is the attempt to correct all forms of malady, including the gestational anomaly leading to the birth of conjoined twins. Abortion in such a case would be a eugenic preemptive strike perhaps based on the hopeless view that medical science will not exceed its current bounds of achievement. Ken Walker's views on the recent birth of twin girls joined at the head in British Columbia ${ }^{1}$ sadly reflect the attitude that such situations are beyond our ability to manage, now and forever. Of course, this would be the case if the trial-and-error approach (the essence of scientific progress) were to be abandoned.

The smiles of the conjoined twins' doctors ${ }^{1}$ reflect hope and courage. Medical anomalies, particularly of this kind, will remain a tragedy only if we abandon our gifts as humans to discover and improve.

\section{Richard F. Poole MB ChB \\ Hudson, Que.}

Competing interests: None declared.

\section{REFERENCE}

I. Walker K. The tragedy that should never have happened. $C M A J$ 2007;177:312.

DOI:I0.I503/cmaj.I070I25

I was interested in Ken Walker's article ${ }^{1}$ as I had just read a discussion of the happiness of conjoined twins in a new book by Harvard psychologist Daniel Gilbert. $^{2}$ Gilbert comments on twins Lori and Reba Schappel, who are joined at the forehead and share a blood supply, part of a skull and some brain tissue. The twins feel that, even were it possible, they would reject surgery to separate them. Gilbert writes, "So here's the question: If this were your life rather than theirs, how would you feel? If you said, 'joyful, playful and optimistic,' ... try to be honest instead of correct. The honest answer is 'despondent, desperate and depressed.' Indeed, it seems clear that no rightminded person could really be happy under such circumstances ... in an exhaustive search of the medical literature, [a] medical historian found the 'desire to remain together to be so widespread among communicating conjoined twins as to be practically universal."” In sum, writes Gilbert, "all claims of happiness are claims from someone's point of view - from the perspective of a single human being whose unique collection of past experiences serves as a context, a lens, a background for her evaluation of her current experience. As much as the scientist might wish for it, there isn't a view from nowhere."

Walker suggests that our concerns about the conjoined twins recently born in British Columbia should be primarily financial in nature. I am moved to quote Kurt Vonnegut, who wrote (in Breakfast of Champions) that a life not worth living combined with an unquenchable will to live is a combination often seen on this planet.

I am glad that Walker is not my doctor, and that he does not have the power to decide who should and who should not be born. Or have that bypass, appendectomy, arthroscopic knee surgery, etc.

After all, we will all end up as worm feed. Timing is, of course, everything.

\section{Beverly R. Akerman MSc}

Professional Writers Association

of Canada

Montréal, Que.

Competing interests: None declared.

\section{REFERENCES}

I. Walker K. The tragedy that should never have happened. CMAJ 2007;177:312.

2. Gilbert D. Stumbling on happiness. Toronto: Vintage Canada; 2006.

DOI:Io.I503/cmaj.I070126

I read with interest the Salon article by Ken Walker. ${ }^{1}$ I am concerned that Walker reduces the discussion about the case of the recent birth of conjoined twins in British Columbia to an argument about the expected health care costs.

In my view, we as physicians should first discuss ethical considerations. The twins' mother refused to have an abortion: Should her physicians or society have forced her to have the procedure without her consent? Now that the twins have been born, to what amount 
of health care and social services (if any) are they entitled? Who is qualified to ascertain the quality of their life?

If we focus solely on monetary issues in discussing this case, does this mean that all decisions about whether or not to treat patients should be based primarily on the expected costs of treatment? We need to consider whether Walker's way of thinking fits with our own attitudes and beliefs about what it means to be a physician.

\section{Manfred Gogol MD}

Department of Geriatrics

Krankenhaus Lindenbrunn

Coppenbruegge, Germany

Competing interests: None declared.

\section{REFERENCE}

I. Walker K. The tragedy that should never have happened. CMAJ 2007;177:312.

DOI:I0.1503/cmaj.I070I27

\section{Disclosing medical errors}

The commentary on disclosing errors to patients by Wendy Levinson and Thomas Gallagher ${ }^{1}$ perpetuates the confusion created by others. ${ }^{2,3}$ Levinson and Gallagher suggest that errors alone lead to harm; if harm is not caused, it is "by chance or because the error was corrected before harm could occur." Statements like this suggest that they have not based their writing on a model of accident causation, such as Reason's well-referenced "Swiss cheese" model, ${ }^{4}$ which describes the complex interplay of the actions of workers, local triggering factors and latent conditions that weaken, breach or bypass defences, thereby contributing to adverse outcomes. Statements such as "some adverse events are preventable - these events can be called errors" are inaccurate; the terms error, adverse event and harm are not synonymous.

Levinson and Gallagher make reference to national guidelines for the disclosure of adverse events that the Canadian Patient Safety Institute is developing with stakeholders "including the Canadian Medical Protective As- sociation and organizations that represent medicine, nursing, pharmacy and health care institutions." ${ }^{1}$ We find it curious that patients and their families, the most important stakeholders, are not mentioned in this list. The guidelines use an arbitrarily chosen definition of an adverse event: "an unexpected event in health care delivery that results in harm and is not attributable to a recognized complication." ${ }^{5}$ This definition markedly restricts the scope of disclosure and is not patient focused.

For patients, the distinctions between the terms errors, adverse events and unexpected complications are not important. Patients experience harm, and regardless of how members of the health care community and legal profession wish to classify it, patients who have suffered harm expect and deserve a timely, supportive and informative conversation about their concerns. Indeed, in 2003 the College of Physicians and Surgeons of Ontario recognized this with the publication of their policy on disclosure of harm. ${ }^{6}$

\section{W. Ward Flemons MD \\ Vice President}

Quality, Safety and Health

Information

Calgary Health Region

Jan M. Davies MSc MD

Professor of Anesthesia

University of Calgary

Bruce MacLeod MD

Medical Director

Clinical Safety Evaluation

Calgary Health Region

Calgary, Alta.

Competing interests: None declared.

\section{REFERENCES}

I. Levinson W, Gallagher TH. Disclosing medical errors to patients: a status report in 2007. CMAJ 2007; I77:265-7.

2. Waite M. To tell the truth: the ethical and legal implications of disclosure of medical error. Health LaW J 2005; I3:I-33.

3. Lemon MR, Hobgood C, Hevia A. Disclosing medical error: a professional standard. Semin Med Pract 2004;7:24-33.

4. Reason J. Managing the risks of organizational accidents. Aldershot (UK): Ashgate Publishing; 1997.

5. Canadian Patient Safety Institute. Draft national guidelines for the disclosure of adverse events. Edmonton: The Institute; 2007. Available: www.patientsafetyinstitute.ca/disclosure.html (accessed 2007 Sept I2).

6. College of Physicians and Surgeons of Ontario. Disclosure of harm. Policy no I-03. Toronto: The College; 2003. Available: www.cpso.on.ca/Policies /disclosure.htm (accessed 2007 Sept I2).

DOI:I0.1503/cmaj.I070II4 